\title{
PENGEMBANGAN SOSIOLOGI KURIKULUM PENDIDIDIKAN ISLAM DI MADRASAH ALIYAH HUSNUL KHOTIMAH KUNINGAN
}

\author{
Saehu Abas \\ UIN Sunan Gunung Djati Bandung \\ e-mail: saekhuabbas1993@gmail.com
}

Abstract: Islamic education curriculum developmentis an attempt of the assessment results through the correction and evaluation of the curriculum, resulting in the effort to change, add or reduce the content or orientation of the educational curriculum, until eventually happen trait development. Relation to the perspectives of sociology education, because they have a process to aim to carry out the development through an approach concepts, values, or the perspective of sociology education. This study therefore, seeks to inform design shape at a time of the implementation of Islamic education curriculum when juxtaposed with the view of educational sociology. The results showed that the design and implementation of educational activities are charged sociology of education in Madrasah Aliyah Husnul Khotimah Kuningan, which is among the activities program includes courses Halaqah Tarbiyah, PDPM (Practice Propagation and Introduction to Community), mukhoyyam Tarbawi or rihlah, the spirit of Eid 'adha sacrifice, the spirit of Eid fitri alms and so forth.

Pengembangan kurikulum pendidikan Islam merupakan suatu upaya dari buah hasil penilaian melalui koreksi dan evaluasi kurikulum, sehingga terjadi usaha untuk merubah, menambahkan atau mengurangi akan isi atau orientasi kurikulum pendidikan, sampai pada akhirnya terjadi sifat pengembangan. Kaitannya dengan pespektif sosiologi pendidikan, kerena memiliki proses sampai tujuan untuk melaksanakan pengembangan tersebut melalui pendekatan konsep, nilai, atau cara pandang sosiologi pendidikan. Demikian penelitian ini, berusaha untuk menginformasikan bentuk desain sekaligus bentuk implementasi kurikulum pendidikan Islam 
apabila disandingkan dengan pandangan sosiologi pendidikan. Hasil penelitian menunjukan bahwa adanya desain dan implementasi kegiatan-kegiatan pendidikan yang bermuatan sosiologi pendidikan di Madrasah Aliyah Husnul Khotimah Kuningan, yang diantara program kegiatan tersebut meliputi program Halaqah Tarbiyah, Praktik Da'wah dan Pengenalan Masyarakat (PDPM), mukhoyyam tarbawi atau rihlah, semangat idul 'adha berqurban, semangat idul fitri bersedekah dan lain sebagainya.

Keywords: Curriculum development, Islamic education, Sociology of education.

\section{Pendahuluan}

Kurikulum memiliki kedudukan tertinggi, sentral dan strategis pada keseluruhan komponen-komponen pendidikan. Sebab hakikat atas proses perjalanan suatu pendidikan sangat dipengaruhi oleh kokoh dan tidaknya suatu bangunan epistemologi kurikulum pendidikan itu ditegakkan. ${ }^{1}$ Pada dasarnya kurikulum tidak hanya berisikan tentang petunjuk teknis materi pembelajaran. Kurikulum merupakan sebuah program terencana dan menyeluruh, yang secara tidak langsung menggambarkan manajemen pendidikan suatu bangsa. Dengan begitu, otomatis kurikulum memegang peran urgen dan strategis dalam menentukan arah kemajuan dunia pendidikan suatu negara. Perannya sebagai penentu arah kemajuan suatu negara, maka prinsip kurikulum tidak hanya berpegang pada prinsip kontinuititas, praktis atau efisiensif dan efektifitas, namun juga memiliki prinsip-prinsip relevansi dan fleksibilitas. ${ }^{2}$

Prinsip relevansi dan fleksibelitas dalam muatan isi kurikulum sejatinya ditujukan sebagai bentuk respon atas

\footnotetext{
1 Ahmad Hasan Ridwan, Dasar-Dasar Epistemologi Islam (Bandung: Pustaka Setia, 2011), 25.

2 Arifuddin Arif, Pengantar Imu Pendidikan Islam (Jakarta: Kultura, 2008), 86.
} 
tantangan-tantangan pendidikan yang terjadi pada laju derasnya perubahan dalam dunia pendidikan modern. Prinsip-prinsip ini pula, tentu tidak hanya ditujukan pada kurikulum pendidikan umum, namun menjadi standar ukuran pada kurikulum pendidikan Islam yang memiliki basis isi muatan-muatan ajaran keagamaan keislaman. Desain kurikulum pendidikan Islam baik pada sisi filosofis, teoretis, maupun praktis sangat berpegang teguh pada ajaran-ajaran yang diamanatkan oleh al-Qur'an dan al-Hadits, sekaligus menjadikannya sebagai sumber rujukan pertama serta sumber pedoman ideal dalam mempraktekkan dunia pendidikan. ${ }^{3}$

Rumusan atas sumber kurikulum pendidikan Islam yang telah ditetapkan, tidak lain karena memiliki tujuan akhir agar setiap elemen-elemen pendidikan mampu memasrahkan seluruh dirinya hanya kepada Allah SWT. Seperti yang telah disampaikan oleh Ali Ashaf, bahwa tujuan akhir pendidikan agama Islam adalah manusia yang menyerahkan diri secara mutlak kepada Allah SWT khususnya, masyarakat dan kemanusiaan pada umumnya. Begitu juga Imam Al-Ghazali menjelaskan, bahwa tujuan pendidikan Islam yang paling utama adalah beribadah dan taqarrub kepada Allah, dan kesempurnaan insani yang tujuannya kebahagiaan dunia akhirat. ${ }^{4}$

Ideal dan sempurnanya konsep kurikulum pendidikan Islam dalam mengejewantahkan ajaran dan nilai-nilai keislaman pada dunia pendidikan, senyatanya tidak dapat terhindar dari sorotan kritik dan tudingan-tudingan dari masyarakat maupun aktifis-aktifis pendidikan pada dunia pendidikan modern. Problematika ini terjadi, tidak lain karena desain atau konsep kurikulum pendidikan Islam dirasa belum mampu memenuhi pasar kebutuhan pendidikan masyarakat serta belum adanya

\footnotetext{
${ }^{3}$ Arifuddin Arif, 37.

${ }^{4}$ C.A Qadir, Philosopy and Science in the Islamic World: Filsafat Dan Ilmu Pengetahuan Dalam Islam, trans. Hasan Basari (Jakarta: Obor Indonesia, 1989), 106.
} 
dampak nyata yang massif-ideal-strategis bagi setiap lini kehidupan masyarakat. Mochtar Buchori misalnya, memberikan komentar bahwa kegagalan pendidikan Islam disebabkan karena praktek pendidikannya hanya memperhatikan aspek kognitif semata dari pertumbuhan kesadaran nilai-nilai agama, dan mengabaikan pembinaan afektif dan konatif-volatif, yakni kemauan dan tekad untuk mengamalkan nilai-nilai ajaran agama secara sosial. Akibatnya terjadi kesenjangan antara pengetahuan dan pengamalan, antara gnosis dan praxis dalam kehidupan bermasyarakat. ${ }^{5}$

Kompleksnya beberapa permasalahan di atas, menegaskan bahwa baik basis teoretis kurikulum dan tujuan kurikulum suatu pendidikan, harus segera dirumuskan secara kultural, bukan doktrinal ataupun struktural. Harus segera diberikan tujuan ideal, baik mikro maupun makro, terutama pendidikan tauhid, agar tidak terjadi ketimpangan di mana hal yang sakral (bidang studi agama) dan di mana hal yang profan (bidang studi umum) saat materi pendidikan agama Islam diajarkan. ${ }^{6}$ Mengingat, kurikulum menjadi arah penting menuju tujuan pendidikan. Dan akan berimbas pada ranah kognitif, afektif dan psikomotorik seorang peserta didik pada keberhasilan belajarnya.

Demikian disimpulkan, pentinganya menghadirkan inovasi-inovasi terbaru dalam melaksanakan pembaharuan atau pengembangan kurikulum pendidikan Islam. Sebagai tujuan menjawab kebutuhan dan kejelasan rumusan kurikulum pendidikan Islam ditengah-tengah pertarungan pendidikan modern. Kedua, pentingnya suatu pengembangan kurikulum, yang tidak hanya bersifat vertikal (hubungan mahluk dengan tuhannya) namun, juga bersifat horisontal (hubungan antar etnis

5 Muhaimin, Pengembangan Kurikulum Pendidikan Agama Islam (Jakarta: Grafindo Persada, 2012), 23.

6 Abdul Munir Mulkhan, Kesalehan Multikultural (Jakarta: PSAP, 2005), 180. 
dan perbedaan manusia). Sehingga, menjadikan konsen peneliti pada arah evaluasi, koreksi serta analisis atas kurikulum pendidikan Islam, sekaligus melihat bentuk desain dan implementasi pengembangan kurikulum pendidikan Islam berbasis sosiologi pendidikan di Madrasah Aliyah Khusnul Khotimah Kuningan.

\section{Pengembangan Kurikulum Perspektif Sosiologi Pendidikan}

Proses pengembangan kurikulum pendidikan Islam memiliki beberapa paradigma. Muhaimin mengklasifikannya dalam tiga pemetaan. ${ }^{7}$ Pertama, paradigm dikotomis yang memandang segala sesuatu dalam dua sisi berlawanan seperti pendidikan agama dan pendidikan non agama. Kedua, paradigma mekanisme sebagai paradigma yang memandang kehidupan terdiri atas berbagai aspek sebagai penanaman dan pengembangan seperangkat nilai kehidupan, yang masingmasing bergerak dan berjalan menurut fungsinya. ${ }^{8}$ Ketiga, paradigma organisme yang berarti susunan bersistem.

Selanjutnya model pendekatan dalam pengembangan kurikulum dibagi dalam empat macam. Pertama, pendekatan subjek akademik yang merupakan tipe penyusunan kurikulum atau program pendidikan berdasarkan sistematisasi disiplin ilmu masing-masing. Pengembangan kurikulum subjek akademis dilakukan dengan cara menetapkan lebih dahulu mata pelajaran apa yang harus dipelajari peserta didik, dan yang diperlukan untuk persiapan pengembangan disiplin ilmu. ${ }^{9}$

Kedua, pendekatan humanistik yang memberikan tempat utama kepada siswa. Mereka bertolak dari asumsi bahwa anak

7 Muhaimin, Paradigma Pendidikan Islam; Upaya Mengefektifkan Pendidikan Agama Islam Di Sekolah (Bandung: Remaja Rosdakarya, 2012), 38.

${ }^{8}$ Muhaimin, 42.

${ }^{9}$ Nana Syaodih Sukmadinata, Pengembangan Kurikulum: Teori Dan Praktik (Bandung: Remaja Rosdakarya, 2017), 80. 
atau peserta didik adalah yang pertama dan utama dalam pendidikannya. Dia adalah subjek yang menjadi pusat kegiatan pendidikan. $^{10}$ Ketiga, pendekatan rekonstruksi sosial yang bersumber pada aliran pendidikan interaksional. Menurut mereka pendidikan bukan upaya sendiri, melainkan kegiatan bersama, interaksi, kerja sama. Melaui interaksi dan kerja sama ini siswa berusaha memecahkan problem-problem yang dialami dalam masyarakat menuju pencarian inovasi atau jalan keluar yang lebih haronis dan kesejahteraan. ${ }^{11}$ Keempat, pendekatan teknologis yang menekankan isi kurikulum tetapi diarahkan bukan pada pemeliharaan dan pengawetan ilmu tersebut tetapi pada penguasaan kompetensi. Suatu kompetensi yang besar diuraikan menjadi prilaku-prilaku yang dapat diamati dan diukur. $^{12}$

Sosiologi pendidikan dalam tulisan ini dimaksudkan untuk memberikan peta pembahasan, batasan pembahasan, landasan pembahasan mengenai pengembangan kurikulum pendidikan Islam melalui potret atau pemetaan paradigma dan pendekatan yang ada. Hal ini dilakukan untuk mendeteksi paradigma mana yang relevan untuk kemudian dikembangkan. Cakupan sosiologi pendidikan terdiri dari relasi sistem pendidikan dengan masyarakat, relasi antara manusia di lembaga pendidikan, pengaruh sekolah terhadap perilaku dan kepribadian semua pihak di lembaga pendidikan dan lembaga pendidikan dalam masyarakat. ${ }^{13}$

10 Nana Syaodih Sukmadinata, Prinsip Dan Landansan Pengembangan Kurikulum (Jakarta: P2LPTK, 1988), 102.

11 Nana Syaodih Sukmadinata, Pengembangan Kurikulum: Teori Dan Praktik, 92.

12 Oemar Hamalik, Dasar-Dasar Pengembangan Kurikulum (Bandung: Remaja Rosdakarya, 2009), 76.

${ }^{13}$ S. Nasution, Sosiologi Pendidikan (Jakarta: Bumi Aksara, 2015), 6-7. 


\section{Metode Penelitian}

Penelitian yang dipilih merupakan jenis penelitian kualitatif melalui pendekatan Deskriptif-Kualitatif. Adapun data yang diperoleh peneliti didapatkan melalui teknik wawancara dengan wakil kepala madrasah bagian kurikulum, guru pendidikan agama dan kepala MA Husnul Khotimah Kuningan. Adapun wawancara dengan jenis data sekunder didapat dari beberapa pihak yang mendukung penelitian ini. Sehingga dapat diketahui dengan jelas tentang bentuk desain dan implementasi pengembangan kurikulum pendidikan Islam. ${ }^{14}$

\section{Desain dan Implementasi Pengembangan Kurikulum Pendidikan Islam di Madrasah Aliyah Husnul Khotimah Kuningan}

Desain pengembangan kurikulum pendidikan Islam merupakan proses perencanaan atau penyusunan kurikulum oleh pengembang kurikulum, atas dasar penilaian, evaluasi atau koreksi sehingga terjadi usaha merubah, mengurangi atau bahkan menambah akan program-program, kegiatan-kegiatan, atau orientasi dalam pelaksanaan proses pendidikan. Kegiatan yang dilakukan agar kurikulum yang dihasilkan dapat menjadi bahan ajar dan bahan acuan yang dapat digunakan untuk mencapai tujuan pendidikan Nasional atau lebih dipersempit kepada tujuan mengimplementasikan nilai-nilai keislaman yang diamanatkan oleh Al-Qur'an maupun Al-Hadits. Kaitannya dengan perspektif sosiologi pendidikan, artinya bahwa sejauh bentuk desain dan implementasi kurikulum pendidikan Islam dikembangkan, senantiasa memiliki hubungan timbal balik, fungsional simbiotik atau relasi fungsional dengan kegiatankegiatan yang memiliki basis sosiologis atau kegiatan-kegiatan sosial-kemasyarakatan. Berdasarkan hasil identifikasi peneliti

14 Burhan Bungin, Penelitian Kualitatif: Komunikasi, Ekonomi, Kebijakan Publik Dan Ilmu Sosial Lainnya (Jakarta: Kharisma Putra Utama, 2007), 110. 
dengan berbagai pihak yang ada di lembaga Madrasah Alihay Husnul Khotimah, ditemukan berbagai penyelenggaraan kegiatan yang memiliki basis sosiologi pendidikan, yakni sebagai berikut.

a. PDPM Reguler atau Halaqah Tarbiyah

PDPM merupakan singkatan dari praktik dakwah dan pengenalan masyarakat, yang program kegiatannya dilaksanakan oleh kelas X MA Husnul Khotimah. Implimentasi jenis kegiatan PDPM Reguler terbagi menjadi dua bagian. Pertama, siswa MA Husnul Khotimah diutus mengajar, membimbing, mempraktikan pengetahuannya sekaligus mengelola lembaga TPA (Taman Pengajian Al-Qur'an) atau lembaga MD (Madrasah Dinyiah) di beberapa desa di kab. Kuningan. Kegiatan ini, dilaksanakan selama satu tahun oleh kelas X MA Husnul Khotimah dan dilaksanakan satu minggu satu kali, yakni setiap hari jum'at. Kedua, kegiatan PDPM Reguler yang dilaksanakan oleh kelas X MA Husnul Khotimah di lembaga-lembaga formal, setingkat SLTP, SMP, MTs sederajat. Dilaksanakan selama tiga bulan, yaitu dibulan januari, februari, maret dan dilaksanakan setiap akhir pekan. Adapun program PDPM Reguler ini sendiri, termasuk dalam program kurilum pendidikan Islam yang sifatnya intensif, artinya dilaksanakan secara rutin atau kontinu oleh lembaga MA Husnul Khotimah.

b. PDPM (Praktik Dakwah dan Pengenalan Masyarakat)

PDPM selanjutnya yaitu kegiatan praktik dakwah dan pengenalan masyarakat yang dilaksanakan oleh kelas XII MA Husnul Khotimah. Implementasi kegiatan PDPM, merupakan suatu kegiatan khusus untuk kelas XII MA Husnul Khotimah, dengan cara mereka terjun langsung serta ikut tinggal langsung bersama masyarakat selama dua pekan. Bentuk kegiatannya meliputi ta'lim di lingkungan-lingkungan pendidikan agama, menghidupkan mushala atau masjid, kujungan atau silaturahmi 
ke rumah-rumah masyarakat, melaksanakan bersih-bersih 100 mushola atau masjid, baksos, penyuluhan kesehatan, tabligh akbar, membentuk irmas, menghidupkan atau mensupport pembuatan karang taruna, membuka taman baca untuk anakanak, mendata sekaligus berkunjung pada orang yang sedang sakit, bazar sembako murah dan lain sembagainya. Untuk waktu kegiatannya ada dibulan oktober untuk tahun ini, dan ada pada tanggal 1-15 oktober 2018. Adapun program PDPM ini sendiri, termasuk dalam program kurilum pendidikan Islam yang sifatnya intensif, artinya dilaksanakan secara rutin atau kontinu oleh lembaga MA Husnul Khotimah.

c. OSHK

OSHK merupakan singkatan dari organisasi siswa Husnul Khatimah, yang mana programnya diisi oleh kelas XI MA Husnul Khotimah. OSHK terdiri dari beberapa bidang, SALAM HK (siswa pecinta alam), Pramuka dan HKPU (Husnul Khotimah pendula umat). Di dalam orgaisasi ini, siswa kelas XI MA Husnul Khotimah dilatih dan dilibatkan untuk menjadi team tanggap bencana atau team relawan ketika terjadi musibah bencana alam. Baik bencana alam berupa banjir, tanah longsor, maupun gempa bumi yang terjadi di beberapa daerah. Adapun beberapa kegiatan yang digerakan oleh OSHK ini sendiri, termasuk dalam program kurilum pendidikan Islam yang sifatnya insidental, artinya dilaksanakan sesuai dengan momentmoment tertentu.

d. Mukhoyyam Tarbawi atau Rihlah

Mukhoyyam tarbawi atau rihlah merupakan kegiatan ektsternal pendidikan Islam, dimana kegiatan belajar siswa, dilaksanakan diluar kelas. Implementasi mukhoyyam tarbawi atau rihlah di MA Husnul Khotimah di desain dalam bentuk camping (berkemah) pada alam terbuka. Kagiatan ini, dilaksanakan oleh kelas X dan kelas XI MA Husnul Khotimah, ketika kelas XII sedang melaksanakan kegiatan UNBK. Di 
dalam kegiatan camping, ada kegiatan mencari jejak. Dimana kegiatan mencari jejak ini, siswa dituntut oleh pembinanya untuk menemukan pos-pos yang diberi arahan dan petunjuk dari pembina, untuk selanjutnya dicari letak pos-pos itu sendiri. Pospos ini biasanya diletakan pada beberapa rumah-rumah penduduk yang dirasa kurang mampu, untuk selanjutnya diberikan sembako oleh siswa yang sedang melaksanakan mukhoyyam tarbawi. Adapun program Mukhoyyam tarbawi atau rihlah ini sendiri, termasuk dalam program kurilum pendidikan Islam yang sifatnya insidental, artinya dilaksanakan sesuai dengan moment-moment tertentu.

e. Ajang Remaja Berprestasi (Aresta)

Ajang Remaja Berpretasi merupakan kegiatan yang kepanitiaan maupun lainnya diurus oleh siswa kelas XI MA Husnul Khotimah. Kegiatan ini diikuti oleh seluruh pihak sekolah, baik siswa dan wali siswa. Dan diantara implementasi pelaksanaannya, terdapat kegiatan lomba-lomba bagi siswa dan yang tidak kalah penting adanya kegiatan peduli dunia Islam. Pelaksanaan kegiatan peduli dunia Islam, dalam memobilisasi dana dapat berupa lelang hasil karya lukisan atau kaligrafi siswa, hasil kerajinan tangan dari siswa, kreatifitas pembuatan seni rupa siswa dan lain sebagainya. Adapun program aresta ini sendiri, termasuk dalam program kurilum pendidikan Islam yang sifatnya intensif, artinya dilaksanakan secara rutin atau kontinu oleh lembaga MA Husnul Khotimah setiap bulan februari.

\section{f. Semangat Idul 'Adha Berqurban}

Program idul 'adha berqurban merupakan kegiatan penyembelihan hewan, baik kambing maupun sapi yang jatuh pada bula idul 'adha. Implementasi kegiatan ini, telah menjadi tradisi bagi siswa satu kali selama belajar di MA Husnul Khotimah untuk mengeluarkan qurban di bulan idul 'adha. Adapun penyaluran daging qurban dilaksanakan oleh seluruh 
civitas akademis lembaga MA Husnul Khotimah, yang selanjutnnya diberikan kepada masyarakat disekitar desa MA Husnul Khotimah atau sering disebut desa penyangga (desa Sadamantra, desa Sumbawa, desa Manis Lor dan desa Manis Kidul), kaum muallaf di Kec. Cigugur, kaum disabilitas, LAPAS (lembaga permasyarakatan) kab. Kuningan, yayasan yatim piatu dan lain sebagainya. Sedangkan program semangat idul 'adha berqurban ini, termasuk dalam program kurilum pendidikan Islam yang sifatnya intensif, artinya dilaksanakan secara rutin atau kontinu oleh lembaga MA Husnul Khotimah.

g. Semangat Ramadhan Bersedekah

Implementasi ramadhan bersedekah merupakan kegiatan saling berbagi, baik berupa bentuk barang maupun nilai nominal uang tertentu diantara satu manusia dengan manusia lainnya secara suka rela atau ikhlas dan dilaksanakan di bulan ramadhan. Pelaksanaan program ini, sudah menjadi budaya bagi siswa MA Husnul Khotimah bersama wali muridnya untuk melaksanakan kunjungan atau silaturahmi ke rumah warga di sekitar, yang diidentifikasi layak diberikah sedekah, seperti warga miskin misalnya, golongan yang memiliki status janda, golongan dhu'afa dan lain sebagainya. Mereka melaksanakan iuran atau patungan bersama, untuk selanjutnya dibelikan sembako dan dibagikan pada golongan-golongan tersebut. Adapun program ini, dilaksanakan satu kali selama bulan ramadhan. Sedangkan kegiatan semangat ramadhan bersedekah, termasuk dalam program kurilum pendidikan Islam yang sifatnya intensif, artinya dilaksanakan secara rutin atau kontinu oleh lembaga MA Husnul Khotimah.

h. Sanlat Ceria atau Pesantren Kilat

Sanlat ceria atau singkatan dari pesantren kilat atau santri kilat merupakan kegiatan membimbing atau mengajar di lembaga formal, informal atau non-formal yang dilakukan oleh siswa MA Husnnul Khotimah di daerah atau wilayahnya 
masing-masing. Implementasi kegiatan ini, dikontrol melalui lembar mutaba'ah yang diberikan oleh setiap wali kelas siswa, yang selanjutnya di isi ketika siswa melaksanakan kegiatan sanlat dan ditanda tangani oleh penanggung jawab yang berada dilapangan. Pelaksanan kegiatannya dilaksankan pada bulan ramadhan atau pada waktu liburan siswa MA Husnul Khotimah dan dilakukan melalui kerjasa lembaga MA Husnul Khotimah bersama konsulat di daerah masing-masing. Fungsi dan peran konsulat atau biasa disebut alumni MA Husnul Khotimah yang sudah menitik karir di daerah masing-masing, yakni sebagai pencari tempat dimana lokasi sanlat itu digulirkan, sebagai pemohon izin kegiatan sanlat itu diselenggarakan atau sebagai tokoh yang membantu mempermudah kegiatan sanlat itu dilaksanakan di daerah masing-masing siswa.

i. Munasharah atau Peduli Dunia Islam

Munasharah atau peduli dunia Islam merupakan kegiatan saling tolong menolong, membantu dalam mengurangi beban penderitaan seseorang atau aktifitas simpati terhadap fenomenfenomena yang terjadi di dunia Islam lainnya. Sepertia di negara Palestina, negara Syuri'ah maupun Rohingnnya. Kegiatan ini, diselenggarakan oleh lembaga MA Husnul Khotimah bersama seluruh siswa, wali siswa dan seluruh civitas akademis MA Husnul Khotimah. Isi kegiatannya meliputi, pertama, mendatangkan tokoh atau masyayikh-masyayikh yang berpengaruh dari Palestina maupun Syuri'ah. Kedua, memperkenalkan tentang kondisi, situasi dan tragedi-tragedi non-kemanusiaan yang terjadi pada umat Islam di belahan Negeri lain, baik di Palestina, Syuri'ah dan Rohingnya. Ketiga, mengadakan infaq bersama, yang selanjutnya ditujukan untuk mengurangi beban kehidupan yang di alami umat Islam diluar sana. Sejauh ini munasharah yang rutin dilakukan setiap tahunnya, yaitu munasharah terhadap Palestina, Syuri'ah dan Rohingnya. Adapun kegiatan munashoroh atau peduli dunia 
Islam ini, termasuk dalam program kurilum pendidikan Islam yang sifatnya intensif, artinya dilaksanakan secara rutin atau kontinu oleh lembaga MA Husnul Khotimah.

j. Husnul Khotimah Peduli Bencana Alam

Husnul Khotimah peduli bencana alam merupakan bentuk aksi tanggap bencana MA Husnul Khotimah terhadap peristiwa atau serangkaian peristiwa yang disebabkan oleh alam, antara lain baik berupa gempa bumi, tsunami, gunung sinabung Meletus di Kab. Karo Sumatera Utara, banjir, kekeringan, angin topan, dan tanah longsor. Beberapa kegiatan yang telah sukses diselenggarakan MA Husnul Khotimah terhadap fenomena bencana alam ini sendiri, seperti banjir atau longsor Cibingbin kab. Kuningan, banjir Garut, gunung sinabung meletus di gempa NTB Lombok, gempa bumi serta tsunami di Palu dan Dongala dan lain sebagainya. Implementasi kegiatan ini, dapat berupa tenaga dengan mangutus siswa MA Husnul Khotimah untuk terjun langsung kelapangan - jika lokasi bencana memungkinkan untuk di jangkau -, membantu membersihkan musholah, masjid atau membantu membersihkan rumah warga yang menjadi korban bencana alam. Selanjutnya, ada pula yang berupa materi, baik berupa nominal uang atau berupa barang, seperti makanan, pakain layak pakai, tenda-tenda pengungsian dan lain sebagainya. Adapun program Husnul Khotimah peduli bencana ini sendiri, termasuk dalam program kurilum pendidikan Islam yang sifatnya insidental, artinya dilaksanakan sesuai dengan moment-moment tertentu.

k. Jalan santai atau Jalan Sehat Bersama Masyarakat

Jalan santai atau jalan sehat bersama masyarakat merupakan bagian olah raga ringan yang menyehatkan serta media berkumpul atau mejalin kebersamaan, mempererat komunikasi atau interaksi melalui kekompakan bersama masyarakat sekitar MA Husnul Khotimah atau masyarakat desa penyangga (masyarakat desa Sadamantra, desa Sumbawa, desa 
Manis Lor dan desa Manis Kidul). Implementasi program ini, termasuk pada kegiatan yang sifatnya kondisional, baik diadakannya ketika harlah lembaga Husnul Khotimah, wisudaan siswa MA Husnul Khotimah atau acara muharraman MA Husnul Khotimah. Bagian dari pelaksanaan kegiatan ini, selain kegiatan jalan sehat atau jalan santay, yaitu kegiatan santunan terhadap anak yatim, santunan terhadap penyandang disabilitas, penjualan sembako murah, pengadaan doorprize bersama masyarakat, yang terkadang isi doorprize dapat berupa umrah. Adapun program jalan santai atau jalan sehat bersama masyarakat, termasuk dalam program kurilum pendidikan Islam yang sifatnya insidental, artinya dilaksanakan sesuai dengan moment-moment tertentu.

1. Hari Syukuran Bumi Bersama Masyarakat

Hari syukuran bumi bersama masyarakat merupakan tradisi ungkapan wujud syukur atas nikmat dari hasil panen sumber daya alam yang melimpah dan dilaksanakan oleh seluruh masyarakat kecamatan Jalaksana kab. Kuningan bersama seluruh civitas akademis dan siswa MA Husnul Kohimah. Implementasi kegiatannya diawali dengan beberapa pertunjutkan kesenia adat, dilanjutkan pada acara makan bersama - ditujukan untuk mempererat ikatan emosional masyarakat dengan lembaga MA Husnul Khotimah - dan diakhiri dengan do'a bersama. Adapun kegiatan syukuran bumi bersama masyarakat, termasuk dalam program kurilum pendidikan Islam yang sifatnya insidental, artinya dilaksanakan sesuai dengan moment-moment tertentu.

Perencanaan pengembangan kurikulum pendidikan Islam perspektif sosiologi pendidikan di Madrasah Aliyah Husnul Khotimah Kuningan adalah proses perencanaan pendidikan Islam yang maksimal sesuai dengan tuntunan kurikulum pendidikan, serta memenuhi kebutuhan peserta didik terhadap ilmu pengetahuan syari'ah dan umumnya, transformasi ilmu 
pengetahuan serta bahasa, dibarengi dengan penanaman moral yang tinggi melalui pemberdayaan nilai-nilai akhlakul karimah, serta pengupayaan terhadap pembentukan jati diri peserta didik untuk memiliki sisi tanggung jawab pribadi dan sosial, sehingga mampu membentuk nilai kesalehan pribadi dan kesalehan sosial, melalui model lembaga pendidikan Islam Boarding School. Perencanaan tersebut, dapat dilihat dari tujuan atau misi yang telah ditetapkan oleh Madrasah Aliyah Husnul Khotimah serta melalui wawancara dari berbagai sumber yang ada. Bahwa perencanaan kegiatan-kegiatan sosial-kemasyarakatan ditujukan untuk membina peserta didik dalam memiliki peran dan tanggung jawab terhadap wilayah sosial, menumbuhkan jiwa atau mental yang kuat, menumbuhkan rasa kedewasaan, menumbuhkan kepedulian sesama, menyebarkan kemaslahatan atau kebaikan sesama, dibarengi dengan penanaman sifat dan sikap nafi'un lighairihi (bermanfaat bagi yang lain).

Seluruh perencanaan atau tujuan yang disebutkan, menunjukan kesesuaian dengan apa yang menjadi komentar Abuddin Nata, bahwa sudah semestinya pendidikan Islam selain memperhatikan tujuan yang hanya bersifat keagamaan, namun juga mendekatkan diri pada pengembangan masyarakat atau agenda-agenda yang berwawasan sosial. Artinya tidak cukup pendidikan Islam mampu mencerdaskan peserta didik dalam pemahaman ilmu agama, cakap dalam beribadah, mahir membaca Al-Qur'an, namun kurang peduli terhadap masyarakat, bahkan tidak mengetahui cara-cara agar berguna di masyarakat. $^{15}$

Adapun paradigma yang yang dikembangkan dalam kurikulum perspektif sosiologi pendidikan di Madrasah Aliyah Husnul Khotimah, yakni melalui pandangan paradigma organisme. Pilihan paradigma ini terlihat dari adanya

\footnotetext{
15 Abuddin Nata, Sosiologi Pendidika Islam (Jakarta: Rajawali Pers, 2014), 33.
} 
pengintegrasian diantara nilai-nilai ilmu pengetahuan, nilai-nilai ilmu agama dan nilai-nilai kesosialan yang dirumuskan dan dipraktikan oleh Madrasah Aliyah Husnul Khotimah dalam penyelenggaraan pendidikan. Dan terdapat pula kerja sama yang harmonis dan saling melengkapi di antara kelompok sekolah, kelompok masyarakat dan wali siswa. Sebagaimana disampaikan Muhaimin bahwa ada tiga paradigma dalam pengembangan kurikulum. Pertama, paradigma dikotomis. Kedua, paradigma mekanisme. Ketiga, paradigma organisme. ${ }^{16}$ Dalam pandangan paradigma organisme Muhaimin lebih lanjut menjelaskan bahwa organisme dalam pengembangan kurikulum pendidikan dapat diidentifikasi melalui pandangan bahwa aktivitas kependidikan merupakan suatu sistem yang terdiri atas komponen-komponen yang hidup bersama dan bekerja sama secara terpadu menuju tujuan tertentu, yaitu terwujudnya hidup yang religius atau dijiwai oleh ajarannilai-nilai agama atau dimensi horizontal dengan nilai-nilai kehidupan sosial atau dimensi vertikal. ${ }^{17}$

Sedangkan pendekatan yang dipilih, sebagaimana Nana Syaodih Sukmadinata membagi empat pendekatan dalam pengembangan kurikulum. Pertama, pendekatan secara subjek akademis. Kedua, pendekatan secara humanistik.Ketiga, pendekatan secara rekonstruksi sosial, dan. Keempat, pendekatan secara teknologis. ${ }^{18}$ Apabila melihat pengembangan kurikulum pendidikan Islam di Madrasah Aliyah Husnul Khotimah, maka dapat diketahui bahwa pendekatan kurikulum yang dikembangkan yakni melalui pendekatan rekonstruksi sosial dengan nilai-nilai sosiologi pendidikannya.

16 Muhaimin, Paradigma Pendidikan Islam; Upaya Mengefektifkan Pendidikan Agama Islam Di Sekolah, 38.

${ }^{17}$ Muhaimin, Pengembangan Kurikulum Pendidikan Agama Islam, 39.

18 Nana Syaodih Sukmadinata, Pengembangan Kurikulum: Teori Dan Praktik, 81 . 
Pengembangan kurikulum rekonstruksi sosial yang dimaksud, sebagaimana yang telah dijelaskan dari hasil wawancara di Madrasah Aliyah Husnul Khotimah, diketahui bahwa adanya proses pendidikan yang tidak hanya terpaku pada ilmu pengetahuan Islam semata, namun membentuk desain pengembangan kurikulum pendidikan Islam yang memiliki pendekatan sosiologi pendidikan, seperti bentuk desain program kurikulum yang meliputi kegiatan Halaqah Tarbiyah, PDPM, Mukhoyyam Tarbawi atau Rihlah, idul adha' berqurban, idul fitri bersedekah,munashoroh atau peduli dunia Islam, kegiatan peduli bencana alam dan lain sebagainya. Seluruh program kegiatan ini, menurut Nasution, menjadi ciri khas nilai sosiologi pendidikan, karena adanya usaha untuk melaksanakan pola-pola interaksi sosial dan peranan sosial dalam masyarakat pendidikan dengan kelompok-kelompok atau masyarakat di luar pendidikan, sehingga diketahui hubungan-hubungan yang fungsional diantara ke dua pihak. ${ }^{19}$

Lebih jauh Abuddin Nata menjelaskan, bahwa upaya mewujudkan pendidikan Islam berbasis sosiologi pendidikan di lingkungan sekolah merupakan suatu wujud bentuk anjuran kegiatan, mengingat di dalamnnya terkandung nilai keseimbangan wawasan tentang pemahaman hablum minallah (hubungan baik dengan Allah SWT) yang disandingkan dengan pemahaman hablum minannas (hubungan baik dengan manusia). ${ }^{20}$ Keterangan ini sebagaimana firman Allah swt dalam surah Ali 'Imran ayat 103: ${ }^{21}$

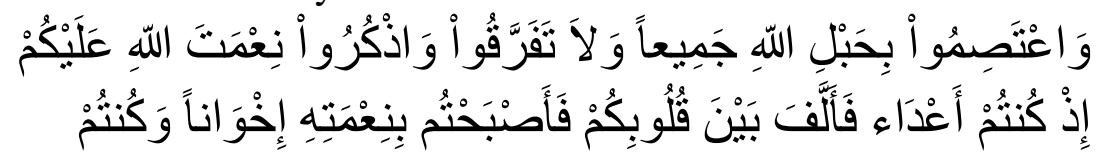

${ }^{19}$ S. Nasution, Sosiologi Pendidikan, 6.

${ }^{20}$ Abuddin Nata, Sosiologi Pendidika Islam, 92.

${ }^{21}$ Al-Kalam, Alkalam Digital: Versi 1.0 (Bandung: Diponegoro, 2009), 103. 


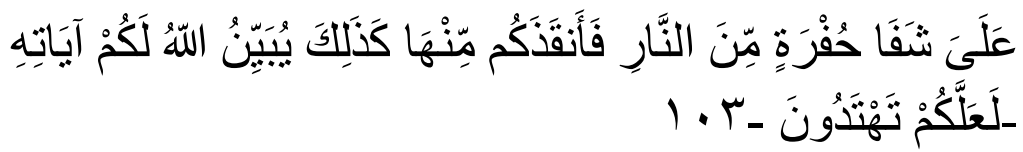

Keterangan ayat di atas menunjukan dengan jelas bahwa fungsi sosiologi pendidikan, yaitu sebagai upaya menyelematkan manusia dari tepi jurang kehancuran, perpecahan dan menjadikannya sebagai kelompok sosial yang bersatu, bersaudara dan tolong menolong, memberikan petunjuk dan mengeluarkan manusia dari kesesatan hidup. Demikian ini, sebagaimana keterangan dari hasil wawancara yang telah di paparkan sebelumnya, Madrasah Aliyah Husnul Khotimah menjalankan kegiatan tersebut melalui bentuk desain pengembangan kurikulum yang di namanakan Halaqah Tarbiyah untuk kelas X, PDPM (Praktik Dakwah dan Pengenalan Masyarakat) untuk kelas XII, serta OSHK (Organisasi Siswa Husnul Khotimah) sebagai wadah pengembangan karakter pribadi sosial untuk kelas XI, melibatkan masyarakat dalam setiap program kegiatan yang diselenggarakan, membuka lapangan pekerjaan untuk masyarakat sekitar, membentuk interkasi harmonis antara wali siswa dan wali murid melalui group whats app, berperan aktif dalam setiap bencana yang dihadapi masyyarakat, dan mengadakan komunikasi terbuka dengan masyarakat sekitar lembaga. Seluruh kegiatan yang ada di dalamnya merupakan bentuk interaksi, komunikasi serta media pembelajaran dalam aksi peduli terhadap persoalan yang dihadapi masyarakat.

\section{Penutup}

Desain dan implementasi kegiatan berbasis sosiologi pendidikan yang dapat dijumpai di Madrasah Aliyah Husnul Khotimah Kuningan menggunakan paradigma pengembangan kurikulum organisme melalui pendekatan rekonstruksi sosial. Hal ini tampak dari berbagai bentuk interaksis atau komunikasi internal maupun eksternal dan pelaksanaan program kegiatan 
yang meliputi kegiatan halaqah tarbiyah untuk kelas XI, PDPM untuk kelas XII, munasharah, mukhoyyam tarbawi atau rihlah dan lain sebagainya.

\section{Daftar Rujukan}

Al-Kalam. Alkalam Digital: Versi 1.0. Bandung: Diponegoro, 2009.

Arif, Arifuddin. Pengantar Imu Pendidikan Islam. Jakarta: Kultura, 2008.

Bungin, Burhan. Penelitian Kualitatif: Komunikasi, Ekonomi, Kebijakan Publik Dan Ilmu Sosial Lainnya. Jakarta: Kharisma Putra Utama, 2007.

Hamalik, Oemar. Dasar-Dasar Pengembangan Kurikulum. Bandung: Remaja Rosdakarya, 2009.

Muhaimin. Paradigma Pendidikan Islam; Upaya Mengefektifkan Pendidikan Agama Islam Di Sekolah. Bandung: Remaja Rosdakarya, 2012.

_. Pengembangan Kurikulum Pendidikan Agama Islam. Jakarta: Grafindo Persada, 2012.

Mulkhan, Abdul Munir. Kesalehan Multikultural. Jakarta: PSAP, 2005.

Nasution, S. Sosiologi Pendidikan. Jakarta: Bumi Aksara, 2015.

Nata, Abuddin. Sosiologi Pendidika Islam. Jakarta: Rajawali Pers, 2014.

Qadir, C.A. Philosopy and Science in the Islamic World: Filsafat Dan Ilmu Pengetahuan Dalam Islam. Translated by Hasan Basari. Jakarta: Obor Indonesia, 1989.

Ridwan, Ahmad Hasan. Dasar-Dasar Epistemologi Islam. Bandung: Pustaka Setia, 2011.

Sukmadinata, Nana Syaodih. Pengembangan Kurikulum: Teori Dan Praktik. Bandung: Remaja Rosdakarya, 2017. 
Saehu Abas

. Prinsip Dan Landansan Pengembangan Kurikulum. Jakarta: P2LPTK, 1988.

178 IJIES, Vol. 1, No. 2, 2018: 159-178 